\title{
PEMBERDAYAAN MASYARAKAT UNTUK MENINGKATKAN PEMBERIAN ASI EKSKLUSIF KELURAHAN AMPEL KOTA SURABAYA
}

\author{
PEOPLE EMPOWERMENT TO INCREASE AN EXCLUSIVE BREASTFEEDING \\ AT AMPEL VILLAGE SURABAYA CITY
}

\author{
Fuad Zulkarnain Rozaq Sugeha ${ }^{1}$, Trias Mahmudiono ${ }^{2}$ \\ ${ }^{1}$ Departemen Gizi Kesehatan - Fakultas Kesehatan Masyarakat - Universitas Airlangga, \\ E-mail: sugeha.fuad@gmail.com \\ ${ }^{2}$ Departemen Gizi Kesehatan - Fakultas Kesehatan Masyarakat - Universitas Airlangga \\ E-mail: trias-m@fkm.unair.ac.id
}

\begin{abstract}
ABSTRAK
ASI adalah cairan hasil sekresi kelenjar payudara Ibu, dan eksklusif apabila diberikan pada bayi sejak kelahiran hingga 6 bulan tanpa menambahkan dan atau mengganti dengan minuman yang lain kecuali obat. Pemberian ASI Eksklusif dapat menurunkan angka kesakitan dan kematian pada bayi. Cakupan ASI Eksklusif di Kelurahan Ampel sejumlah 59,2\% dari 1418 balita hal ini menunjukkan capaian ASI Eksklusif di Kelurahan Ampel dibawah standar (77\%). Tujuan kegiatan ini adalah memberdayakan masyarakat untuk meningkatkan pemberian ASI Eksklusif di Kelurahan Ampel Kota Surabaya. Manfaat kegiatan ini untuk memandirikan masyarakat dalam meningkatkan status kesehatan masyarakat khususnya dalam pemenuhan ASI Eksklusif di Kelurahan Ampel. Metode pelaksanaan kegiatan ini berupa FGD dan indepth interview yang diikuti oleh $10 \mathrm{ibu}$, penyuluhan yang diikuti oleh 44 orang, leadership, dan kaderisasi pemantau pemberian ASI Eksklusif yang diikuti oleh 7 orang. Hasil FGD menunjukkan bahwa perlu adanya intervensi di bidang kesehatan tentang pemberian ASI Eksklusif di Kelurahan Ampel. Inovasi kegiatan yang dapat dilakukan untuk meningkatkan pemberian ASI Eksklusif melalui program ASI eKsklusif Bayi kUat (ASIK BU). Program ASIK BU di Kelurahan Ampel dilakukan melalui kegiatan yang berupa kaderisasi karang taruna dan penyuluhan kepada WUS, Bumil dan Busui. Saran dari kegiatan ini berupa perlu adanya pemantauan dari penanggung jawab puskesmas Sidotopo secara berkala untuk melakukan monitoring dan evaluasi terhadap pelaksanaan program ASIK BU. Diharapkan masyarakat berkomitmen penuh dalam melaksanakan program ASIK BU. Pemerintah setempat dapat memberikan dukungan sosial maupun material salah satunya dalam bentuk pemberian penghargaan kepada kader dan ibu yang dapat memberikan ASI secara eksklusif.
\end{abstract}

Kata kunci: ASI Eksklusif, Program Kesehatan, Pemberdayaan Masyarakat

\begin{abstract}
Breastmilk is a fluid secretion from mother mammary gland, and called exclusive when breastmilk given to newborn until six months without adding and or replace with another fluid except medicine. Exclusive Breastfeeding can reduce infant morbidity and mortality rate. Breastfeed performance at Ampel Village is $59,2 \%$ from 1418 infants. It showed that is under standard of breastfeed (77\%). Aim of this program is made empowerment to increase exclusive breastfeed performance at Ampel Village. Benefit of this program is Ampel People can increase health status especially exclusive breastfeed by themselves. Method of this program by using FGD, indepth interview that followed by 10 mothers, health education was followed 44 people. Leadership and forming of breastfeed cadres is followed by 7 peoples. FGD Result showed that necessity of health intervention especially exclusive breastfed monitoring at Ampel Village. Innovation can be done by ASI eKsklusif Bayi kUat (ASIK BU) program. ASIK BU at Ampel village done by forming of breastfeed cadres and gave health education to fertile woman, breastfeed mother, and pregnant woman. Recommendation of this program is periodically monitored and evaluated by Puskesmas Sidotopo. Ampel Village people must put fully committed for this program. Government should support socially and materially which one by giving reward to mother who finished exclusive breastfeed and cadre who helping mother.
\end{abstract}

Keywords: Exclusive Breastfeeding, Health Program, People Empowerment 


\section{PENDAHULUAN}

ASI adalah cairan hasil sekresi kelenjar payudara Ibu, dan eksklusif apabila diberikan pada bayi sejak kelahiran hingga 6 bulan tanpa menambahkan dana tau mengganti dengan minuman yang lain. Pemberian ASI Eksklusif pada bulan pertama kehidupan bayi dapat menurunkan angka kesakitan dan kematian salah satunya penyakit diare. Bayi baru lahir belum memiliki sistem kekebalan tubuh yang baik seperti orang dewasa. Tubuh bayi belum mampu untuk melawan bakteri atau virus penyebab penyakit, tubuh bayi dilindungi oleh antibodi yang diterima melalui ASI karena pada ASI memiliki mekanisme preventif secara imunologik dengan adanya antibodi yang terdapat dalam kolostrum dan zat gizi lainnya. ASI juga bersifat steril, berbeda dengan sumber susu lainnya seperti susu formula atau cairan lain yang dibuat secara manual yang tidak diketahui akan terkontaminasi oleh bakteri dan organisme lain yang dapat menyebabkan diare ${ }^{1}$.

ASI mengandung nutrisi yang cukup dan zat kekebalan untuk melindungi balita dari infeksi². ASI mengandung protein, lemak, vitamin, mineral, air, dan enzim yang dibutuhkan oleh bayi. Manfaat ASI yaitu, mengurangi risiko kekurangan nutrisi karena zat besi yang yang terkandung dalam ASI diserap lebih baik, pertumbuhan bakteri Lactobacillus bifidus dalam usus oleh ASI dapat mencegah bakteri penyebab penyakit lainnya dalam saluran pencernaan serta untuk mencegah terjadinya diare. ASI mengandung zat laktoferin, kolostrum ASI kaya antibodi dan zat antiinfeksi.

World Health Organization (WHO) merekomendasikan sebaiknya bayi hanya diberi Air Susu Ibu (ASI) selama paling sedikit 6 bulan, dan pemberian ASI dilanjutkan sampai bayi berusia dua tahun yang disertai dengan pemberian makanan pelengkap. Pada tahun 2003, pemerintah Indonesia telah merekomendasikan lamanya pemberian ASI Eksklusif dari 4 bulan menjadi 6 bulan. Beberapa penelitian epidemologis juga menyatakan bahwa ASI dapat melindungi bayi dari penyakit infeksi, seperti diare, otitis media, dan infeksi saluran pernafasan akut bagian bawah.

Data Profil Kesehatan Jawa Timur, presentasi pemberian ASI Eksklusif di Provinsi Jawa Timur sejumlah 31,3\% ${ }^{3}$. Cakupan ASI Eksklusif Provinsi Jawa Timur sejumlah 74\%, hal ini tidak sesuai dengan target capaian yaitu sejumlah 77\%. Dari 37 Kota di Provinsi Jawa Timur, sejumlah 15 Kota memenuhi target capaian ASI Eksklusif dan 23 Kota lainnya dengan cakupan dibawah 77\%. Jumlah Bayi 0-6 bulan di Kota Surabaya sejumlah 19.359 dan yang diberikan ASI Eksklusif sejumlah $12.603(65,1 \%)$ bayi ${ }^{4}$. Cakupan ASI Eksklusif di Kelurahan Ampel sejumlah 59,2\% dari 1418 balita. Data PKL Mahasiswa Fakultas Kesehatan Masyarakat Universitas Airlangga 2018 bahwa terdapat hubungan ASI Eksklusif terhadap kejadian diare $(p=0,009)$. Tujuan kegiatan ini adalah memberdayakan masyarakat untuk meningkatkan pemberian ASI Eksklusif di Kelurahan Ampel Kota Surabaya.
Manfaat kegiatan ini untuk memandirikan masyarakat dalam meningkatkan status kesehatan masyarakat khususnya dalam pemenuhan ASI Eksklusif di Kelurahan Ampel.

\section{PENDEKATAN/METODE YANG DIGUNAKAN}

Kegiatan ini menggunakan metode kualitatif dengan melakukan Focus Group Discussion (FGD) dan Indepth Interview untuk memperoleh informasi mendalam tentang riwayat pemberian ASI Eksklusif kepada bayinya. FGD dilakukan setelah di Balai RW 13 yang diikuti oleh 10 peserta. FGD dan interview direkam dan dicatat.

\section{PEMBAHASAN}

Hasil Focus Group Discussion (FGD) diperoleh bahwa terdapat 7 dari 10 orang yang tidak dapat memenuhi pemberian ASI Eksklusif kepada bayinya. Alasan Ibu tidak dapat memberikan ASI Eksklusif diantaranya; (1) Kurangnya pengetahuan ibu terhadap kecukupan nutrisi dari ASI untuk bayi 0-6 bulan, (2) Mudahnya mendapatkan susu formula, (3) Budaya turun temurun memberikan makanan selain ASI pada bayi sebelum 6 bulan (“di lotek") agar bayi kenyang, (4) Produksi ASI tidak adekuat, dan (5) Ibu bermotivasi rendah dalam pemberian ASI.

Penelitian yang dilakukan Rosyid (2017) ${ }^{5}$ tentang hubungan antara pengetahuan Ibu dan IMD dengan Praktik ASI Eksklusif menunjukkan bahwa terdapat pengaruh tingkat pengetahuan ibu mengenai ASI Eksklusif dengan keberhasilan praktik pemberian ASI Eksklusif. Kurangnya pengetahuan ibu dalam penelitian ini dibuktikan dari data karakteristik ibu sejumlah 48,7\% berpendidikan SD, 15,4\% Berpendidikan SMP, 33,3\% berpendidikan SMA. Ibu yang berpendidikan rendah tidak tahu cara memberikan ASI secara Eksklusif kepada bayinya. Ibu yang berpendidikan rendah cenderung meniru cara menyusui bayi berdasarkan pengalaman orang tua dan mertua ibu tersebut. Pengetahuan merupakan modal yang dapat digunakan sebagai dasar pemberian ASI Eksklusif untuk mencukupi nutrisi dan imunitas bayi.

Orang tua dan mertua sebagai role model dalam pemberian nutrisi pada bayi, pengalaman orang tua sebelumnya akan digunakan ibu pada anaknya. Hal ini sesuai dengan hasil penelitian ini bahwa terdapat ibu yang memberikan makanan/ minuman selain ASI kepada bayinya berdasarkan budaya turun temurun dari orang tuanya. Berdasarkan penelitian Hajaroh (2013) $)^{6}$ tentang hubungan social budaya dengan keberhasilan pemberian ASI Eksklusif pada ibu menyusui di Posyandu wilayah Desa Srigading Sanden Bantul Yogyakarta juga menunjukkan adanya hubungan sosial budaya dengan keberhasilan pemberian ASI Eksklusif. Sosial budaya dapat mempengaruhi seseorang berperilaku. Perilaku pemberian 
ASI Eksklusif bila tidak didukung oleh kebudayaan setempat tidak akan tercapai.

Penelitian yang dilakukan oleh Azriani(2014) ${ }^{7}$ tentang keberhasilan Pemberian ASI Eksklusif menunjukkan bahwa Keberhasilan pemberian ASI Eksklusif dipengaruhi oleh tenaga kesehatan, suami, dan motivasi diri. Penelitian Nurliawati $(2010)^{8}$ tentang Faktor-faktor yang berhubungan dengan produksi Air Susu Ibu pada Ibu pasca seksio sesarea di wilayah Kota dan Kabupaten Tasikmalaya juga menunjukkan bahwa ada hubungan motivasi dengan pemberian ASI. Seorang ibu yang tidak termotivasi dalam memberikan ASI Eksklusif kepada bayinya dapat mengganggu kondisi psikologis ibu dan dapat menghambat proses let down refleks sehingga ASI mengalami bendungan dan tidak mengalir9-11. Penelitian tersebut sesuai dengan hasil penelitian ini bahwa terdapat Ibu yang tidak memberikan ASI Eksklusif dikarenakan memiliki motivasi yang rendah dalam pemberian ASI Eksklusif kepada bayinya serta memiliki pengetahuan yang rendah.

Balita yang tidak diberikan ASI Eksklusif selama enam bulan berisiko 14 kali lebih tinggi mengalami penyakit infeksi. Penelitian Puput di Rumah Sakit Kediri bahwa bayi yang semakin lama diberi ASI, dapat menurunkan kejadian diare ${ }^{12}$. Penelitian Istyaningrum pada bayi usia 6-24 bulan di Kelurahan Bendungan Kecamatan Cilegon tahun 2010, menunjukkan bahwa bayi yang tidak diberi ASI Eksklusif lebih banyak yang menderita diare sebesar 66\%, daripada yang diberi ASI ekslusif 12,5\%. Bayi yang tidak diberi ASI Eksklusif berpeluang sebesar 13 kali terkena diare dibandingkan bayi yang diberi ASI Eksklusif ${ }^{13}$. Bayi yang tidak diberikan ASI Eksklusif rentan terjangkit penyakit dikarenakan dalam ASI terdapat zat imunitas yaitu immunoglobulin yang berfungsi membentuk imunitas dasar pada tubuh serta dapat meningkatkan kekebalan tubuh. Perlu adanya upaya untuk mensosialialisasikan pentingnya ASI Eksklusif kepada seluruh

masyarakat kalangan remaja maupun suami dalam memotivasi dan mendampingi pemberian ASI Eksklusif kepada bayi, serta perlu diberikan pendidikan kesehatan kepada WUS tentang pentingnya ASI Eksklusif dalam mempersiapkan kehamilan hingga menyusui bayi.

Pengetahuan tentang ASI Eksklusif yang kurang perlu ditingkatkan dengan memberikan penyuluhan kepada WUS, Bumil, dan Busui diharapkan mampu menyiapkan diri untuk memberikan ASI Eksklusif kepada bayinya. Pendidikan kesehatan dilakukan dalam bentuk penyuluhan, diskusi tanya jawab, kuis, demonstrasi perawatan payudara dan menunjukkan video tentang manfaat ASI Eksklusif. Pendidikan kesehatan diharapkan dapat meningkatkan pengetahuan, kesadaran dan partisipasi ibu dalam pemberian ASI Eksklusif kepada bayi. Serangkaian pendidikan kesehatan dalam kegiatan ini diberi nama ASIK BU (ASI eKsklusif Bayi kUat). Dengan memberikan nama kegiatan yang menarik dan mudah diingat mampu memotivasi ibu untuk memberikan ASI Eksklusif.

Program ASIK BU sebagai salah satu kegiatan pemberdayaan masyarakat di bidang kesehatan yang berfokus pada pemberian ASI Eksklusif. Pemberdayaan masyarakat melibatkan pemuda desa melalui organisasi Karang Taruna di Kelurahan Ampel untuk berpartisipasi dalam mendata, memantau, melakukan pembinaan dan melaporkan kepada Puskesmas Sidotopo jika terdapat ibu yang sedang dalam tahap menyusui bayinya yang berusia 0-6 bulan. Kaderisasi dilakukan dalam 4 kegiatan yaitu penyuluhan, leadership, technical meeting dan penandatanganan komitmen dalam mendukung pemberian ASI Eksklusif kepada bayi di Kelurahan Ampel. Diharapkan partisipasi masyarakat dan cakupan ASI di Kelurahan Ampel dapat meningkat setelah adanya kegiatan program ASIK BU.

Kaderisasi dilakukan pada tanggal 28 Januari 2018 di balai RW 13. Kaderisasi diawali dengan mengundang perwakilan Karang Taruna Kelurahan Ampel kegiatan ini dihadiri 7 orang $(70 \%)$ dari 10 perwakilan karang taruna yang ditargetkan datang pada kaderisasi ini. Tujuan dari mengumpulkan perwakilan karang taruna untuk membentuk kader ASIK BU. Kegiatan kaderisasi menggunakan media slide power point, video, game leadership, dan simulasi. Setelah perwakilan karang taruna terkumpul, dilakukan penyuluhan materi untuk meningkatkan pengetahuan dan wawasan kader tentang ASI Eksklusif dan dapat memberikan penyuluhan kepada busui jika diperlukan, setelah itu diberikan training leadership and teamwork yang bertujuan untuk antar kader dapat bekerjasama secara organisasi dalam melakukan pemantauan pemberian ASI Eksklusif. Kegiatan selanjutnya yang dilakukan berupa simulasi pendataan, pemantauan, pembinaan dan pelaporan jika terdapat Ibu yang sedang menyusui bayi 0-6 bulan. Simulasi diawali dengan survei lapangan ke setiap RW untuk mendata jumlah ibu yang memiliki bayi 0-6 bulan, kemudian menanyakan riwayat kehamilan, persalinan, anak ke berapa, riwayat menyusui, kendala pemberian ASI Eksklusif, melakukan penyuluhan kepada ibu menyusui, pemasangan stiker pemantauan ibu menyusui pada jendela/pintu depan rumah, dan mencatat pada lembar logbook rekapitulasi ibu menyusui bayi 0-6 bulan serta melaporkan secara rutin setiap bulan kepada penanggung jawab pemantauan ASI Eksklusif di Puskesmas Sidotopo. Kegiatan pengkaderan berlangsung dengan baik, hal ini ditunjukkan dengan adanya antusiasme dari peserta kaderisasi saat penyuluhan, leadership and teamwork, dan simulasi, kegiatan ini diakhiri dengan penandatanganan lembar komitmen kader terhadap pemantauan pemberian ASI Eksklusif di Kelurahan Ampel.

Kegiatan penyuluhan untuk meningkatkan pengetahuan WUS dan ibu dilakukan pada tanggal 29 Januari 2018 di depan Balai RW 13. Kegiatan penyuluhan dihadiri 44 orang $(62,85 \%)$ dari 70 orang yang diundang. Kehadiran peserta 
penyuluhan sudah melebihi target yang ditentukan yaitu $60 \%$ kehadiran peserta. Penyuluhan menggunakan media banner, leaflet, stiker, slide power point dan alat peraga badan. Peserta menunjukkan keaktifan dalam membahas mitos dan fakta yang terjadi di masyarakat tentang pemberian ASI Eksklusif. Peserta mampu menjawab 3 pertanyaan dalam kuis. Peserta juga mampu melakukan praktik perawatan payudara. Sejumlah 5 orang bertanya kepada fasilitator tentang ASI Eksklusif saat berdiskusi tanya jawab.

Serangkaian kegiatan ASIK BU didukung oleh Puskesmas Sidotopo, Kepala Lurah Ampel dan Camat Semampir serta masyarakat Ampel pada umumnya. Pemberdayaan dilakukan untuk dapat meningkatkan partisipasi masyarakat terhadap pembangunan kelurahan khususnya pada kesehatan dalam pemberian ASI Eksklusif untuk bayi. Bayi merupakan calon penerus masa depan yang harus dipersiapkan kecukupan nutrisi dan status kesehatan yang baik semenjak sebelum lahir agar dapat terlahir generasi penerus yang berkualitas. Pemberdayaan masyarakat ASIK BU diharapkan mampu meningkatkan cakupan pemberian ASI Eksklusif di Kelurahan Ampel sehingga upaya promotif dapat dilakukan oleh masyarakat secara mandiri.

\section{PENUTUP}

\section{Kesimpulan}

Hasil FGD menunjukkan bahwa perlu adanya intervensi di bidang kesehatan tentang pemberian ASI Eksklusif di Kelurahan Ampel. Inovasi kegiatan yang dapat dilakukan untuk meningkatkan pemberian ASI Eksklusif melalui program ASI eKsklusif Bayi kUat (ASIK BU). Program ASIK BU di Kelurahan Ampel dilakukan melalui kegiatan yang berupa kaderisasi karang taruna dan penyuluhan kepada WUS, Bumil dan Busui. Program ASIK BU didukung oleh Camat Semampir, Puskesmas Sidotopo dan Kepala Lurah Ampel serta masyarakat kelurahan Ampel pada umumnya.

\section{Saran}

Saran dari kegiatan ini berupa perlu adanya pemantauan dari penanggung jawab puskesmas Sidotopo secara berkala untuk melakukan monitoring dan evaluasi terhadap pelaksanaan program ASIK BU. Diharapkan masyarakat berkomitmen penuh dalam melaksanakan program ASIK BU. Pemerintah setempat dapat memberikan dukungan sosial maupun material salah satunya dalam bentuk pemberian penghargaan kepada kader dan ibu yang dapat memberikan ASI secara eksklusif.

\section{REFERENSI}

Badan Penelitian dan Pengembangan Kesehatan. Riset Kesehatan Dasar (RISKESDAS) 2013. Laporan Nasional 2013 (2013). doi:1 Desember 2013

Adriani, M. Peranan Gizi Dalam Siklus Kehidupan. (Kencana Prenadamedia Group, 2012).

Kemenkes. Buku Saku Pemantauan Status Gizi dan Indikator Kinerja Gizi Tahun 2015, 42-84 (2016). doi:17 November 2016

Dinkesprovjatim. Profil Kesehatan Provinsi Jawa Timur Tahun 2016. (2016).

Rosyid, Z. N. \& Sumarmi, S. Hubungan Antara Pengetahuan Ibu dan IMD Dengan Praktik ASI Eksklusif The Relationship Between Mother's Knowledge and Early Breastfeeding Initiation With Exclusive Breast-Feeding Practices. 406-414 (2017). doi:10.20473/amnt. v1.i4.2017.406-414

Hidayati, H. Hubungan Sosial Budaya Dengan Keberhasilan Pemberian ASI Eksklusif pada Ibu Menyusui di Posyandu wilayah Desa Srigading Sanden Bantul Yogyakarta. (Stikes Aisyiyah Yogyakarta, 2013).

Azriani, D. Keberhasilan Pemberian ASI EKsklusif. J. Heal. Qual. Vol. 4 No. 2 Mei 2014,Hal.77-141 4, 77-141 (2014).

Nurliawati, E. Faktor-Faktor yang Berhubungan dengan Produksi Air Susu Ibu pada Ibu Pasca Seksio Sesarea di Wilayah Kota dan Kabupaten Tasikmalaya. (Universitas Indonesia, 2010).

Poedianto D.H. Kiat Sukses Menyusui. (Aspirasi Pemuda, 2002).

Suradi \& Tobing. Manajemen Laktasi. (Perinasia, 2004).

Soetjiningsih. ASI, petunjuk untuk tenaga kesehatan. (EGC, 2005).

Puput, S. Perilaku Pemberian ASI Terhadap Frekuensi Diare pada Anak Usia 6-24 Bulan di Ruang Anak Rumah Sakit Baptis Kediri. (2011).

Yurilla, I. Hubungan Antara Pemberian ASI Eksklusif dengan Kejadian Diare dan Faktor- faktor Risiko pada Bayi Berusia 6-12 Bulan di Kelurahan Bendungan Kecamatan Cilegon. Fakultas Kedokteran dan Ilmu Kesehatan Universitas (2010). 
Fuad Zulkarnain Rozaq Sugeha, dkk.: Pemberdayaan Masyarakat Untuk Meningkatkan Pemberian ASI Eksklusif

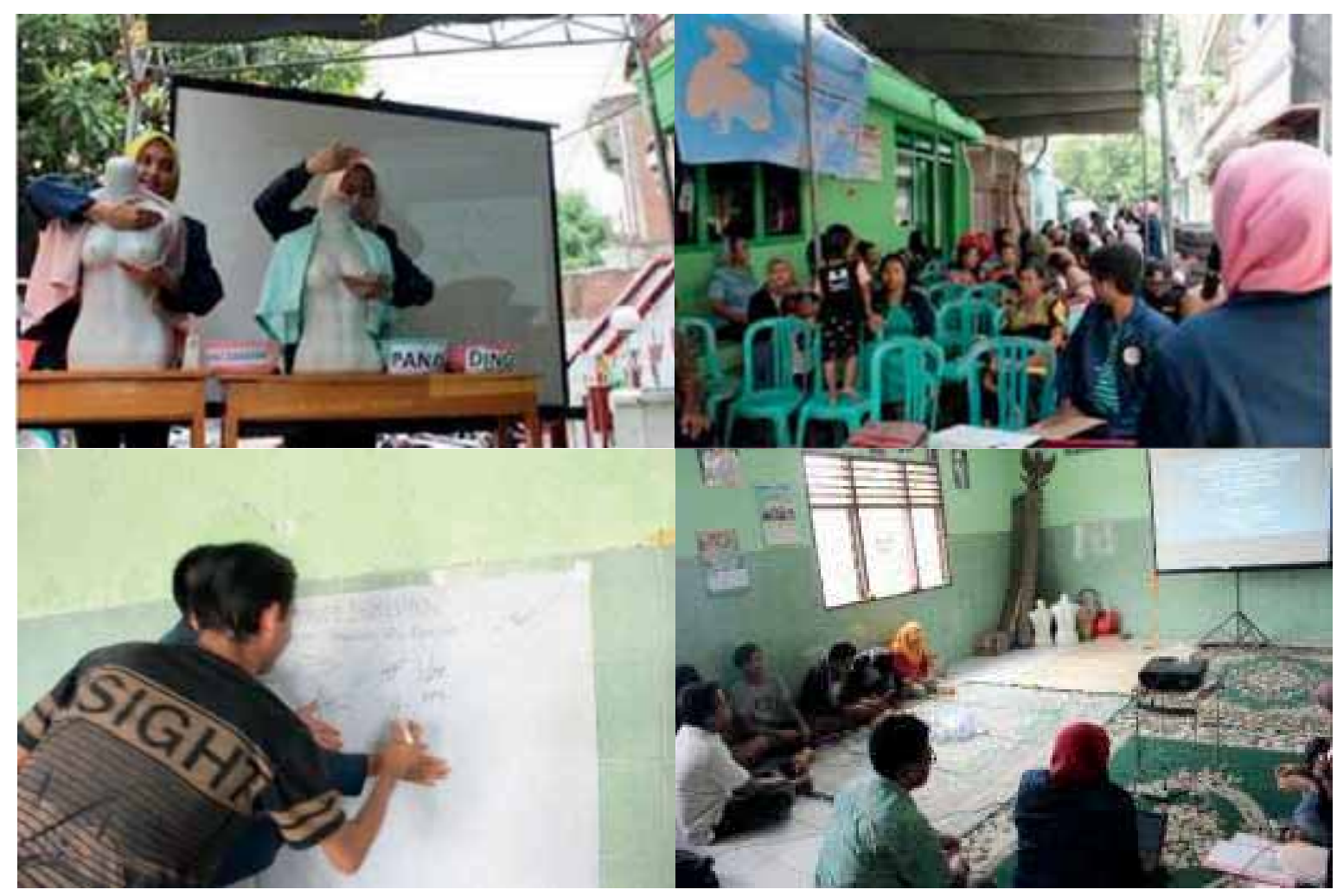

Gambar 1. Dokumentasi kegiatan Pemberdayaan Masyarakat untuk meningkatkan Pemberian ASI Eksklusif 